\title{
How Does Energy Production Respond to the COVID-19 Pandemic? Evidence From China
}

\author{
Di Chen ${ }^{1}$, Haiqing $\mathrm{Hu}^{1}$, Ming-bo Zheng ${ }^{2}$ \\ 1 School of economics and management, Xi'an University of Technology, China, ${ }^{2}$ School of Economics and Management, Chang'an University, China \\ Keywords: covid-19, energy production, renewable energy production \\ https://doi.org/10.46557/001c.22324
}

Asian Economics Letters

Vol. 2, Issue 2, 2021

We investigate the effect of the COVID-19 pandemic on energy production in 30 Chinese provinces. Using data for the January 2018 to December 2020 period, we conclude that the pandemic has negatively influenced energy production. Moreover, we show that the negative impact of COVID-19 on traditional energy production is more than on renewable energy production. Our results pass robustness tests.

\section{Introduction}

The outbreak of the novel coronavirus (COVID-19) has threatened human life and halted economic and social growth globally. To control its spread, the global response has been lockdowns (resulting in factory closures), travel bans, and social distancing (Alfano \& Ercolano, 2020; Phan \& Narayan, 2020). While these policies have contained the spread of the virus, they have also exerted heavy social and economic costs, creating greater economic uncertainty and challenging global economic recovery (He, Niu, et al., 2020; Lan et al., 2020; Yan \& Qian, 2020).

In this paper, we focus on China's energy sector and evaluate how it responded to the COVID-19 pandemic. Our motivation has roots in role of the energy sector in economic recovery in the post-epidemic era. Understanding China's energy sector is important because China is the world's largest energy producer, consumer, and a significant importer and exporter of renewable energy equipment (Cornelius \& Story, 2007).

Our hypothesis is that COVID-19 has had a negative impact on China's energy production. We argue that there is a theoretical connection between COVID-19 and energy production for the following reasons. First, the COVID-19 pandemic has caused great uncertainty to the economic recovery (Iyke, 2020b; Narayan, 2020a). This uncertainty has disrupted economic activity globally. As far as China is concerned, in the first quarter of 2020, the growth rate of national GDP fell by 6.8\% year-on-year, and China's energy consumption is expected to decline too (Alfano \& Ercolano, 2020). Second, economic slowdown has caused unemployment, significant reduction in transportation activities, which have reduced the demand for energy. Thus, energy production has declined.
Using data for 30 Chinese provinces, we conclude that the COVID-19 pandemic negatively impacted China's energy production. We show that the negative impact of COVID-19 on traditional energy production has been more than on renewable energy production. The robustness test based on a different econometric approach (namely the generalized method of moments (GMM) estimator) confirms this conclusion.

Our main contribution is to show how that COVID-19 has led to a fall in traditional energy production and renewable energy production by $14.5 \%$ and $9.8 \%$, respectively. It follows that while both types of energy production have been impacted by the pandemic, the effect on renewable energy production has been less than traditional energy production. These results complement existing research on the impact of COVID-19 on the economy (Dash et al., 2021; Haldar \& Sethi, 2020a; Tisdell, 2020) and the impact on energy (Devpura \& Narayan, 2020; Fu \& Shen, 2020; GilAlana \& Monge, 2020; Gu et al., 2020; He, Sun, et al., 2020; Huang \& Zheng, 2020; Iyke, 2020a; Liu et al., 2020; Narayan, 2020b; Qin et al., 2020; Salisu et al., 2020).

\section{Data and Methodology}

Our panel dataset contains monthly data for 30 Chinese provinces from January 2018 to December 2020. The variable symbols, measurement and data sources are shown in Table 1.

We construct the panel fixed effects regression model to test the impact of COVID-19 on energy production because this model helps overcome the endogenous problem caused by missing variables to a certain extent. The model is as follows:

\footnotetext{
a Corresponding author email: 1652492101@qq.com

1 See special issues on COVID-19 by Sha \& Sharma (2020) and Sharma \& Sha (2020).
} 
Table 1: Variables Symbols Measurement and Data Source

\begin{tabular}{|c|c|c|c|}
\hline Variable Symbols & & Measurement & Data source \\
\hline $\operatorname{lnTEP}$ & & Logarithm of the total energy production & \\
\hline $\operatorname{lnTREP}$ & Dependent variable & Logarithm of the traditional energy production & National Bureau of Statistics \\
\hline $\ln R E P$ & & Logarithm of the renewable energy production & \\
\hline COVID-19 & Explanatory variable & The number of COVID-19 confirmed cases & Wind database \\
\hline$C P I$ & & Consumer price index & \\
\hline PPI & & Producer price index & \\
\hline IAV & Control variable & Fixed asset investment completed amount & National Bureau of Statistics \\
\hline INA & & Industrial added value growth rate & \\
\hline Trade & & Import and export trade amount & \\
\hline
\end{tabular}

This table reports the variable symbols, measurement, and data sources. The traditional energy mainly includes oil, coke, kerosene, gasoline, fuel oil, and raw coal, while renewable energy mainly includes solar energy, water conservancy, firepower, and wind power. The total energy production is the sum of all types of energy production. We convert different energy units into standard coal, in which the unit is ten thousand tons.

$$
\begin{aligned}
\ln E P_{i t}= & \alpha_{0}+\alpha_{1} C O V I D-19_{i t}+\alpha_{2} C P I_{i t} \\
& +\alpha_{3} P P I_{i t}+\alpha_{4} I A V_{i t}+\alpha_{5} I N V_{i t} \\
& +\alpha_{6} T R A D E_{i t}+\mu_{i}+\varepsilon_{i t}
\end{aligned}
$$

$E P$ is energy production (i.e. $T E P, T R E P$, or $R E P$ ). Here, in addition to those variables defined in Table $1, \mu$ is the individual fixed effect of the provinces; the subscripts $i$ and $t$ represent the province and year, respectively; $\alpha_{0}$ represents the constant term; and $\alpha_{1}, \alpha_{2}, \alpha_{3}, \alpha_{4}, \alpha_{5}$ and $\alpha_{6}$, represent the regression coefficients.

\section{Empirical results \\ A. Empirical results of the total energy production}

In Table 2, Panel A presents descriptive statistics. In Panel B, the first column shows the effect of COVID-19 on the total energy production. We see that the pandemic has a negative effect on China's total energy production. For each additional confirmed case of COVID-19, the total energy output decreases by $14.9 \%$. This means that COVID-19 reduces total energy production. The potential reason is that the pandemic has made economic recovery uncertain, prompting energy producers to reduce production consistent with the subdued demand. The outbreak of COVID-19 has also led to the introduction of a variety of pandemic prevention and control policies (Haldar \& Sethi, 2020b). These efforts have affected social and economic development, thereby reducing the demand for energy. Meanwhile, COVID-19 has increased the transportation and storage costs of energy, such as oil and coal, due to the stagnation in transportation. This led to energy producers reducing energy production to in order to reduce production costs.

\section{B. Empirical results of traditional energy production and renewable energy production}

From results in Panel B, we see that COVID-19 has a significantly negative effect on traditional energy production and renewable energy production. By comparison, traditional energy production and renewable energy production fall by $14.5 \%$ and $9.8 \%$ for each COVID-19 confirmed case, respectively.

We, therefore, arrive at an interesting conclusion that the negative impact of COVID-19 on traditional energy production is more than that on renewable energy. This finding is likely to be related to the characteristics of the different types of energy. Traditional energy production, for instance, includes kerosene, fuel oil, and coal, which are resource-intensive and labor-intensive, requiring a large amount of labor to complete energy production. Strict COVID-19 prevention and control measures made it difficult for workers to return to work, and a large number of workers became stranded, resulting in insufficient operating efficiency of enterprises. By contrast, renewable energy includes solar energy, wind energy, and water energy. These are technology-intensive energy types and they are less dependent on labor.

To stimulate recovery of the renewable energy industry, the Chinese government introduced the subsidy policies, such as promoting fuel cell vehicles to "replace subsidies with rewards", extending the period of the crude oil subsidy policy and easing financial pressure within the new energy industry chain. All these factors may have assisted in mitigating the negative impact of the pandemic on renewable energy production. Further research on this is warranted.

\section{Robustness Test}

We adopt the GMM estimator to confirm the robustness of the regression results. From Table 3 , the Wald values indicate the regression results are significant. The Hansen test results show the validity of the instruments. In addition, the values of first and second order autoregressive coefficients reject and accept that the null hypothesis, respectively, indicating that the model does not have a second-order serial correlation problem. We find that COVID-19 has a negative effect on total energy production, traditional energy production, and renewable energy production, which is consistent with the results from our earlier panel regression model. Overall, therefore, our conclusions on the effect of COVID-19 on energy production are robust. 
Table 2: Summary of the variables and main results of fixed effect estimation

\begin{tabular}{|c|c|c|c|c|c|c|}
\hline \multicolumn{7}{|c|}{ Panel A: Summary statistics } \\
\hline Variable & $\mathrm{N}$ & S.D. & Mean & Max & Min & Median \\
\hline $\ln T E P$ & 1080 & 2.5126 & 5.0626 & 8.9545 & 0 & 5.5817 \\
\hline InTREP & 1080 & 2.5024 & 5.0153 & 8.9501 & 0 & 5.5094 \\
\hline $\operatorname{InREP}$ & 1080 & 1.3427 & 2.4291 & 4.1950 & 0 & 2.8556 \\
\hline COVID-19 & 1080 & 1832.229 & 80.3232 & 59754 & 0.0000 & 0.0000 \\
\hline CPI & 1080 & 1.2752 & 102.4238 & 106.9100 & 98.1 & 102.3 \\
\hline PPI & 1080 & 3.9673 & 100.507 & 116.7 & 82.1 & 100 \\
\hline IAV & 1080 & 12.054 & 1.1212 & 28.6000 & -82.8000 & 3.9 \\
\hline INA & 1080 & 5.0317 & 4.6826 & 22.5000 & -46.9000 & 5.2 \\
\hline Trade & 1080 & 14600000 & 7967799 & 108000000 & 4056.18 & 2458526 \\
\hline \multicolumn{7}{|c|}{ Panel B: Results of the fixed effect estimation method } \\
\hline Variable & \multicolumn{2}{|c|}{ Model 1: $\ln T E P$} & \multicolumn{2}{|c|}{ Model 2: InTREP } & \multicolumn{2}{|c|}{ Model 3: InREP } \\
\hline \multirow[t]{2}{*}{ COVID-19 } & \multicolumn{2}{|c|}{$-0.149^{* *}$} & \multicolumn{2}{|c|}{$-0.145^{* *}$} & \multicolumn{2}{|c|}{$-0.098^{* * *}$} \\
\hline & \multicolumn{2}{|c|}{$(-2.34)$} & \multicolumn{2}{|c|}{$(-2.28)$} & \multicolumn{2}{|c|}{$(-3.16)$} \\
\hline $\mathrm{CPI}$ & \multicolumn{2}{|c|}{$\begin{array}{c}-0.192^{* * *} \\
(-2.92)\end{array}$} & \multicolumn{2}{|c|}{$\begin{array}{c}-0.189^{* * *} \\
(-2.89)\end{array}$} & \multicolumn{2}{|c|}{$\begin{array}{c}-0.111^{* * *} \\
(-3.47)\end{array}$} \\
\hline PPI & \multicolumn{2}{|c|}{$\begin{array}{c}-0.279^{* * *} \\
(-4.48)\end{array}$} & \multicolumn{2}{|c|}{$\begin{array}{c}-0.276^{* * *} \\
(-4.46)\end{array}$} & \multicolumn{2}{|c|}{$\begin{array}{c}-0.156^{* * *} \\
(-5.15)\end{array}$} \\
\hline IAV & \multicolumn{2}{|c|}{$\begin{array}{l}-0.131^{*} \\
(-1.76)\end{array}$} & \multicolumn{2}{|c|}{$\begin{array}{c}-0.127^{*} \\
(-1.72)\end{array}$} & \multicolumn{2}{|c|}{$\begin{array}{c}-0.082^{* *} \\
(-2.28)\end{array}$} \\
\hline INA & \multicolumn{2}{|c|}{$\begin{array}{l}0.900^{* * *} \\
(13.23)\end{array}$} & \multicolumn{2}{|c|}{$\begin{array}{l}0.891^{* * *} \\
(13.18)\end{array}$} & \multicolumn{2}{|c|}{$\begin{array}{c}0.446 \\
(13.51)\end{array}$} \\
\hline TRADE & \multicolumn{2}{|c|}{$\begin{array}{c}1.004^{* * *} \\
(9.02)\end{array}$} & \multicolumn{2}{|c|}{$\begin{array}{l}0.991^{* * *} \\
(8.96)\end{array}$} & \multicolumn{2}{|c|}{$\begin{array}{l}0.555^{* * *} \\
(10.29)\end{array}$} \\
\hline Cons & \multicolumn{2}{|c|}{$\begin{array}{c}5.063^{* * *} \\
(82.94)\end{array}$} & \multicolumn{2}{|c|}{$\begin{array}{c}5.015^{* * *} \\
(82 . .73)\end{array}$} & & \\
\hline$F$ & & & & & & \\
\hline
\end{tabular}

This table has two parts. Panel A reports the descriptive statistics of our variables. We report observations (N), mean (Mean), standard deviation (S.D.), minimum (Min), median (Median), and maximum (Max) values. Panel B has the results of the fixed effect estimation: Model 1 presents the results of the impact of COVID-19 on InTEP, while Model 2 and Model 3 present the results for $\operatorname{lnTREP}$ and $\ln R E P$, respectively. The values in brackets are the $p$-value. Lastly, ${ }^{* * * * * *}$ and * denote significance at the $1 \%, 5 \%$ and $10 \%$ levels, respectively.

\section{Conclusion}

As the largest energy producer in the world, China's energy production is undergoing profound changes due to the COVID-19 pandemic. Therefore, this paper aims to solve the research problem of how does energy production respond to the COVID-19 pandemic. We find that COVID-19 has significantly reduced energy production, especially traditional energy production.

Governments thus need to speed up the distribution and development of the energy industry in the post-epidemic era and enhance the stability of the energy industry system. The transformation and upgrading of the traditional energy industry need to take technological transformation and human substitution as the main directions.

\section{Acknowledgments}

We would like to thank the editor and the anonymous reviewers for helpful comments and suggestions. We also ac- knowledge financial support from the National Natural Science Foundation of China (72072144, 71672144, 71372173, 70972053), Research Fund for the National Soft Science Research Program (2014GXS4D153), the Doctoral Program of Higher Education (20126118110017), the key project of Shaanxi soft science research plan (2019KRZ007), Science and Technology Research and Development Program of Shaanxi Province (2021KRM183, 2017KRM059, 2017KRM057, 2014KRM28-2), Research Program Funded by Shaanxi Provincial Education Department (2015JZ021), Key Project of Shaanxi Provincial Development and Reform Commission (SJ-2019-000046-4), and Key Projects of Social Science Planning of Xi'an (17J85).

Submitted: February 01, 2021 AEST, Accepted: April 07, 2021 AEST 
Table 3: Results of the System GMM estimation method

\begin{tabular}{|c|c|c|c|}
\hline \multirow[t]{2}{*}{ Variable } & Model 4 & Model 5 & Model 6 \\
\hline & InTEP & InTREP & $\ln R E P$ \\
\hline $\ln T E P(-1)$ & $\begin{array}{l}0.400^{* * *} \\
(38.57)\end{array}$ & & \\
\hline $\ln T R E P(-1)$ & & $\begin{array}{l}0.400^{* * *} \\
(22.63)\end{array}$ & \\
\hline $\ln R E P(-1)$ & & & $\begin{array}{l}0.415^{* * *} \\
(16.27)\end{array}$ \\
\hline \multirow[t]{2}{*}{ COVID-19 } & $-0.218^{*}$ & $-0.215^{*}$ & $-0.088^{* *}$ \\
\hline & $(-1.68)$ & $(-1.83)$ & $(-2.11)$ \\
\hline$C P I$ & $\begin{array}{l}-0.007 \\
(-1.05)\end{array}$ & $\begin{array}{l}-0.002 \\
(-0.17)\end{array}$ & $\begin{array}{c}-0.023^{* * *} \\
(-2.71)\end{array}$ \\
\hline$P P I$ & $\begin{array}{c}-0.182^{* * *} \\
(-11.31)\end{array}$ & $\begin{array}{c}-0.167^{* * *} \\
(-6.67)\end{array}$ & $\begin{array}{c}-0.090^{* * *} \\
(-7.82)\end{array}$ \\
\hline$I A V$ & $\begin{array}{l}-0.034 \\
(-1.24)\end{array}$ & $\begin{array}{l}-0.030 \\
(-0.87)\end{array}$ & $\begin{array}{c}-0.071^{* * *} \\
(-5.15)\end{array}$ \\
\hline INA & $\begin{array}{c}0.410^{* * *} \\
(25.53)\end{array}$ & $\begin{array}{c}0.399^{* * *} \\
(12.26)\end{array}$ & $\begin{array}{l}0.200^{* * *} \\
(15.65)\end{array}$ \\
\hline TRADE & $\begin{array}{l}0.062^{*} \\
(1.76)\end{array}$ & $\begin{array}{c}0.067 \\
(1.27)\end{array}$ & $\begin{array}{l}0.119^{* * *} \\
(4.55)\end{array}$ \\
\hline Cons & $\begin{array}{c}3.467^{* * *} \\
(46.34)\end{array}$ & $\begin{array}{l}3.420^{* * *} \\
(33.69)\end{array}$ & $\begin{array}{l}1.629^{* * *} \\
(22.14)\end{array}$ \\
\hline Wald & $4635.8^{* * *}$ & $5390.02^{* * *}$ & $1499.47^{* * *}$ \\
\hline$A R(1)$ & $\begin{array}{l}-5.045 \\
(0.000)\end{array}$ & $\begin{array}{l}-4.941 \\
(0.000)\end{array}$ & $\begin{array}{l}-4.897 \\
(0.000)\end{array}$ \\
\hline$A R(2)$ & $\begin{array}{l}-0.275 \\
(0.783)\end{array}$ & $\begin{array}{l}-0.254 \\
(0.799)\end{array}$ & $\begin{array}{c}0.869 \\
(0.385)\end{array}$ \\
\hline Hansen & $\begin{array}{c}25.14 \\
(0.156)\end{array}$ & $\begin{array}{c}24.05 \\
(0.194)\end{array}$ & $\begin{array}{c}26.64 \\
(0.113)\end{array}$ \\
\hline
\end{tabular}

This table reports the robustness test results. Models 4 to 6 present results of the impact of COVID-19 on $\ln \ln P$, $\ln T R E P$, and $\ln R E P$, respectively. (-1) represents the one period lag of the variable. The Hansen test is used to determine whether the instrumental variables are valid. We report the $z$-values for the null hypothesis of instrument validity. The ArellanoBond autoregressive (AR) test is used to determine whether there is a serial correlation problem in the residual term. The values in brackets are the $p$-value. Lastly, $* * * * * *$, and $*$ denote statistical significance at the $1 \%, 5 \%$, and $10 \%$ levels, respectively. 


\section{REFERENCES}

Alfano, V., \& Ercolano, S. (2020). The efficacy of lockdown against COVID-19: A cross-country panel analysis. Applied Health Economics and Health Policy, 18(4), 509-517. https://doi.org/10.1007/s40258-020-0 0596-3

Cornelius, P., \& Story, J. (2007). China and global energy markets. Orbis, 51(1), 5-20. https://doi.org/1 $\underline{0.1016 / j . o r b i s .2006 .10 .002}$

Dash, D. P., Sethi, N., \& Dash, A. K. (2021). Infectious disease, human capital, and the BRICS economy in the time of COVID-19. MethodsX, 8, 101202. https://d oi.org/10.1016/i.mex.2020.101202

Devpura, N., \& Narayan, P. K. (2020). Hourly oil price volatility: The role of COVID-19. Energy Research Letters, 1(2). https://doi.org/10.46557/001c.13683

Fu, M., \& Shen, H. (2020). COVID-19 and corporate performance in the energy industry. Energy Research Letters, 1(1), 12967. https://doi.org/10.46557/001c.129 $\underline{67}$

Gil-Alana, L. A., \& Monge, M. (2020). Crude oil prices and COVID-19: Persistence of the shock. Energy Research Letters, 1(1), 13200. https://doi.org/10.4655 7/001c.13200

Gu, X., Ying, S., Zhang, W., \& Tao, Y. (2020). How do firms respond to COVID-19? First evidence from Suzhou, China. Emerging Markets Finance and Trade, 56(10), 2181-2197. https://doi.org/10.1080/1540496 $\underline{\mathrm{x} .2020 .1789455}$

Haldar, A., \& Sethi, N. (2020a). The News Effect of COVID-19 on Global Financial Market Volatility. Bulletin of Monetary Economics and Banking, 24, 33-58. https://doi.org/10.21098/bemp.v24i0.1464

Haldar, A., \& Sethi, N. (2020b). The Effect of Countrylevel Factors and Government Intervention on the Incidence of COVID-19. Asian Economics Letters, 1(2). https://doi.org/10.46557/001c.17804

He, P., Niu, H., Sun, Z., \& Li, T. (2020). Accounting index of COVID-19 impact on Chinese industries: A case study using big data portrait analysis. Emerging Markets Finance and Trade, 56(10), 2332-2349. http s://doi.org/10.1080/1540496x.2020.1785866

He, P., Sun, Y., Zhang, Y., \& Li, T. (2020). COVID-19's impact on stock prices across different sectors - An event study based on the Chinese stock market. Emerging Markets Finance and Trade, 56(10), 2198-2212. https://doi.org/10.1080/1540496x.2020.1 785865
Huang, W., \& Zheng, Y. (2020). COVID-19: Structural changes in the relationship between investor sentiment and crude oil futures price. Energy Research Letters, 1(2), 13685. https://doi.org/10.46557/001c.13 $\underline{685}$

Iyke, B. N. (2020a). COVID-19: The reaction of US oil and gas producers to the pandemic. Energy Research Letters, 1(2), 13912. https://doi.org/10.46557/001c.13 $\underline{912}$

Iyke, B. N. (2020b). Economic Policy Uncertainty in Times of COVID-19 Pandemic. Asian Economics Letters, 1(2). https://doi.org/10.46557/001c.17665

Lan, C., Huang, Z., \& Huang, W. (2020). Systemic Risk in China's Financial Industry Due to the COVID-19 Pandemic. Asian Economics Letters, 1(3), 18070. http s://doi.org/10.46557/001c.18070

Liu, L., Wang, E.-Z., \& Lee, C.-C. (2020). Impact of the COVID-19 pandemic on the crude oil and stock markets in the US: A time-varying analysis. Energy Research Letters, 1(1), 13154. https://doi.org/10.4655 7/001c.13154

Narayan, P. K. (2020a). Oil price news and COVID-19-Is there any connection? Energy Research Letters, 1(1), 13176. https://doi.org/10.46557/001c.13 $\underline{176}$

Narayan, P. K. (2020b). Did bubble activity intensify during COVID-19? Asian Economics Letters, 1(2), 17654. https://doi.org/10.46557/001c. 17654

Phan, D. H. B., \& Narayan, P. K. (2020). Country responses and the reaction of the stock market to COVID-19-a Preliminary Exposition. Emerging Markets Finance and Trade, 56(10), 2138-2150. http s://doi.org/10.1080/1540496x.2020.1784719

Qin, M., Zhang, Y.-C., \& Su, C.-W. (2020). The Essential Role of Pandemics: A Fresh Insight into the Oil Market. Energy Research Letters, 1(1). https://doi.o rg/10.46557/001c.13166

Salisu, A. A., Vo, X. V., \& Lawal, A. (2020). Hedging oil price risk with gold during COVID-19 pandemic. Resources Policy, 70, 101897. https://doi.org/10.1016/ j.resourpol.2020.101897

Sha, Y., \& Sharma, S. S. (2020). Research on Pandemics Special Issue of the Journal Emerging Markets Finance and Trade. Emerging Markets Finance and Trade, 56(10), 2133-2137. https://doi.org/10.108 0/1540496x.2020.1795467 
Sharma, S. S., \& Sha, Y. (2020). Part A: Special Section on COVID-19 Research. Emerging Markets Finance and Trade, 56(15), 3551-3553. https://doi.or $\mathrm{g} / 10.1080 / 1540496 x .2020 .1858617$

Tisdell, C. A. (2020). Economic, social and political issues raised by the COVID-19 pandemic. Economic Analysis and Policy, 68, 17-28. https://doi.org/10.101 6/j.eap.2020.08.002
Yan, L., \& Qian, Y. (2020). The Impact of COVID-19 on the Chinese Stock Market: An Event Study Based on the Consumer Industry. Asian Economics Letters, 1(3). https://doi.org/10.46557/001c.18068 